\title{
Inhibitory effect of FK506 and Cyclosporine A on the growth and invasion of human liver cancer cells
}

\author{
Manabu Sakai, Hidenori Miyake, Seiki Tashiro"), Yuushi Okumura, and Hiroshi Kido² \\ ${ }^{1)}$ Department of Digestive and Pediatric Surgery, The University of Tokushima School of Medicine, \\ and ${ }^{2}$ Division of Enzyme Chemistry, Institute for Enzyme Research, The University of Tokushima, \\ Tokushima, Japan
}

\begin{abstract}
Background : The prognosis of liver transplantation for liver cancer is determined by recurrence in the liver graft. In this study, the effects of immunosuppressors, FK506 and cyclosporine $A(\mathrm{CsA})$ on the migration of liver cancer cells were investigated.

Methods : The effects of FK506 at concentrations of 1-100 ng/mL and CsA at 1-1000ng/mL on the growth of poorly and well differentiated human hepatocellular carcinoma cell lines, HLE and HuH-7, respectively, were examined. After treatment of these cells with FK506 and CsA, the growth of these cells, their cytotoxicities and invasion assay on the Matrigel basement membrane invasion chamber were evaluated. In addition, the effects of FK506 and CsA on the changes in the production of a soluble intercellular adhesion molecule-1 (sICAM-1) of these cells were measured.

Results : FK506 and CsA at concentrations of 1-10 $\mathrm{ng} / \mathrm{mL}$ inhibited the growth of both HLE and HuH-7 and those immunosuppressors at concentrations over $100 \mathrm{ng} / \mathrm{mL}$ exhibited cytotoxicity on these cells. FK506 at concentration of $1 \mathrm{ng} / \mathrm{mL}$ significantly inhibited the invasion of poorly differentiated HLE, but not well differentiated HuH-7, after treatment for 2-5 days in culture (p<0.05), but FK 506 at $10 \mathrm{ng} / \mathrm{mL}$ showed less inhibitory efficient. CsA at concentrations of 1-10 $\mathrm{ng} / \mathrm{mL}$, however, did not inhibit or transiently inhibited the invasion of both cell lines. The production of ICAM-1 in HLE and HuH-7 was suppressed by FK506 at concentrations of 1-10 $\mathrm{ng} / \mathrm{mL}$ after treatment for 3-5 days but the effect was not significant in the initial phase at days 1-2 and the last phase at days 5-6.

Conclusions : FK506, but not CsA, at a clinical dose of $1 \mathrm{ng} / \mathrm{mL}$ significantly inhibited the invasion of the poorly-differentiated HLE, but not HuH-7 and also inhibited the production of sICAM-1 in HLE. J. Med. Invest. 51 : 63-69, February, 2004
\end{abstract}

Keywords : FK 506, cyclosporine A, liver cancer cell, invasion, ICAM-1

\section{INTRODUCTION}

In liver transplantation for liver cancer, the presence of micro cancer cells in the recipient's blood is a problem leading to recurrence in the transplanted

Received for publication November 20, 2003 ; accepted December $15,2003$.

Address correspondence and reprint requests to Manabu Sakai Department of Digestive and Pediatric Surgery, The University of Tokushima School of Medicine, Kuramoto-Cho,Tokushima 770-8503, Japan and Fax : +81-88-631-9698. liver. For colonization of micro liver cancer cells in the liver graft, as for metastasis and liver invasion by cancers of digestive organs, it is essential that floating cancer cells are disseminated in blood, then adhere to vascular endothelial cells in the liver graft and pass through the cell membrane forming thick basement membrane similar to vascular endothelial cells, unlike the normal liver. In this study, using a cell membrane consisting of components similar to those of liver grafts with thick basement membrane in ischemia reperfusion, the effects of immunosuppressors FK 
506 and cyclosporine $\mathrm{A}(\mathrm{Cs} \mathrm{A})$ on permeation of cancer cells through the basement membrane of liver grafts and invasion/metastasis were investigated. Focusing on adhesion of cancer cells, the effects of FK506 and CsA on an adhesion molecule, ICAM-1, was also investigated.

\section{MATERIALS AND METHODS}

\section{Cell lines and culture}

Two human HCC cell lines with different clinical characteristics, such as poorly differentiated type cell line (HLE) and the well-differentiated type cell line (HuH-7), were obtained from Japan health sciences foundation and used in this study. Both cell lines were maintained in RPMI 1640 medium (Gibco, Grand Island, NY, USA) containing $10 \%$ fetal calf serum (FCS) at $37^{\circ} \mathrm{C}$ under $5 \% \mathrm{CO}_{2}$. The cells were seeded into $75 \mathrm{~cm}^{2}$ flasks (Sumitomo, Akita, Japan), grown to confluence. The cells in the early stationary phase were washed 3 times with phosphate-buffered saline (PBS) (Nissui Pharmaceutical Co Ltd, Tokyo, Japan), and the cells in the conditioned medium were used for experiments.

\section{Chemicals}

FK506 (Fujisawa Pharmaceutical Company, Osaka, Japan) and CsA (Sandoz, Basel, Suitzerland) were dissolved in ethanol as stock solutions and were diluted at various concentrations with culture media before use. It was confirmed that the final concentrations of ethanol do not affect the growth and viability of the cells.

\section{Research Design}

\section{Cell-growth analysis}

Both HLE and HuH-7 cells were cultured as monolayers under the conditions described above to reach confluence. After washing 3 times with PBS, the cells in condition medium containing $10 \%$ FCS were seeded into 24-well round bottom microtest plate (FALCON 3047, Becton Dickinson Microbiology Systems, CA, USA) and then cultured for 6 days. The cells at $2 \times 10^{4}$ per well in a 24-well plate were treated with FK506 and CsA at various concentrations of $1-1000 \mathrm{ng} / \mathrm{mL}$ for additional 6 days. Viable cells were counted with a hemocytometer after trypan blue staining.

\section{Evaluation of cytotoxicity}

Both HLE and HuH-7 cells were cultured in 24-well cell plate $\left(2 \times 10^{4}\right.$ cells/well) with or without FK506 or CsA at concentrations described above. At the late exponential phase of cell growth on day 5 for HLE and on day 4 for HuH-7, FK506 and CsA were removed by washing and then cells were further cultured in RPMI 1640 containing $10 \%$ FCS. Viable cells were counted using trypan blue staining and presented as \% control value, regarding the cell numbers in the control group as $100 \%$.

\section{Invasion assay}

The Matrigel invasion chamber (Bection Dickinson Labware, Bedford, MA, USA) consists of 8.0 micron pore size $\left(1 \times 10^{5}\right.$ pores $\left./ \mathrm{cm}^{2}\right)$ polyethylene terephthalate (PET) membrane chamber coated with a consistently uniform layer of Matrigel basement membrane matrix $\left(100 \mu \mathrm{g} / \mathrm{cm}^{2}\right)$. The Matrigel basement membrane matrix contains laminin, collagen type $I V$, heparan sulfate proteoglycan and entactin, being similar to the matrix between the portal vein and the hepatocytes in the liver. The human hepatic cancer cell lines were detached from the culture flasks by the conditioned media. The cells were then washed 3 times with culture media, suspended at $2 \times 10^{4}$ cells in $100 \mu \mathrm{L}$ in the upper comportment of the Transwell insert. FK506 and CsA were added to culture media at concentrations of 1,10 , and $100 \mathrm{ng} / \mathrm{mL}$ and $1,10,100,1000 \mathrm{ng} / \mathrm{mL}$, respectively, and culture media without addition of these reagents were used as a control experiment. FK506 concentrations in media of 24 well chamber or of the upper compartment in the invasion assays were measured by Enzyme immunoassay and CsA concentrations by Radio immunoassay. To the lower compartment, $600 \mu \mathrm{L}$ of the media containing $20 \mu \mathrm{g} / \mathrm{mL}$ of fibronection were added. The chambers were incubated at $37^{\circ} \mathrm{C}$ in $5 \% \mathrm{CO}_{2}$ for 6 days. The numbers of cancer cells in the upper compartment and those that invaded into the lower compartment on days one through six of culture were calculated by trypan blue exclusion test. Furthermore, cancer cells on the upper surface of the PET membrane were fixed in methanol and stained with hematoxylin-eosion using Diff-Quick Stain kit (Baxter), and the number of these cells was counted under a light microscope $(\times 200)$. Percent ratio of the invaded cells in the lower compartment was defined as follows :

$\%$ invasion $=$ [number of cancer cells that invaded into the lower compartment/the number of cancer cells in the upper compartment + number of cancer cells that invaded into the lower compartment $] \times 100$

\section{Analysis of the levels of soluble ICAM-1(sICAM-1) in human cancer cells}

The levels of sICAM-1 in culture media produced 


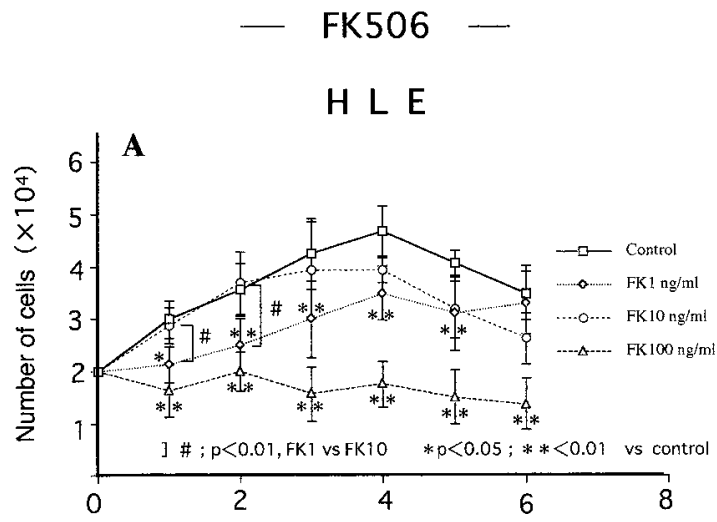

CsA

H L E

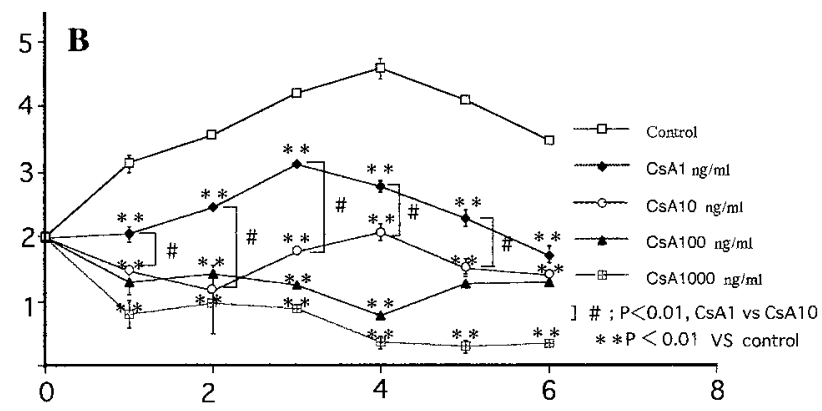

$\mathrm{HuH}-7$

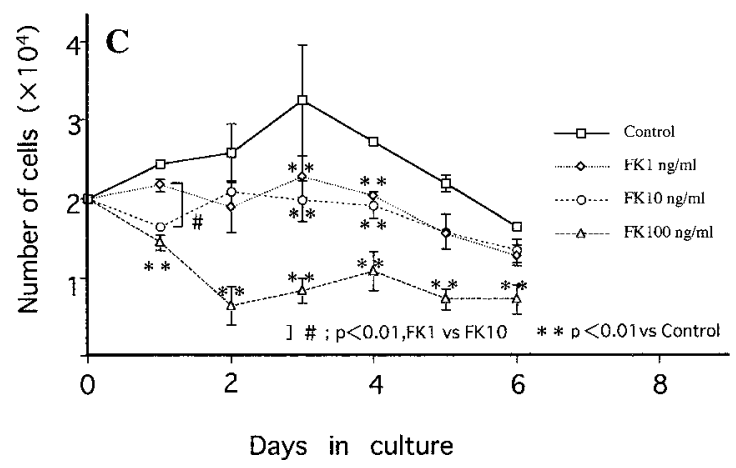

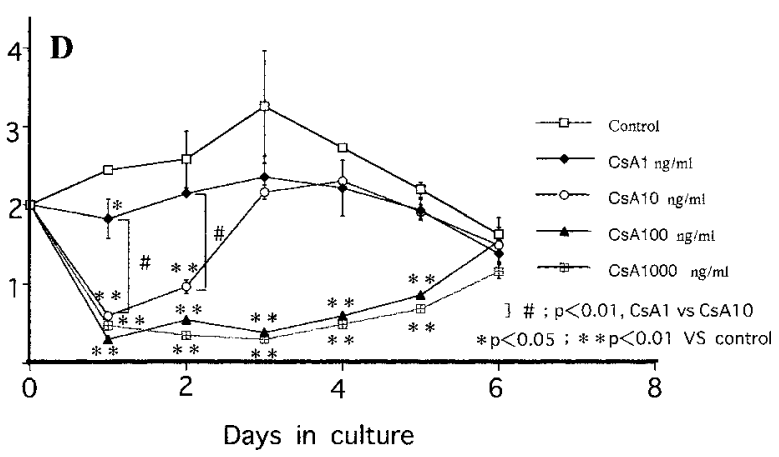

Figure. 1. Inhibition of the growth of human liver cancer cells, HLE and HuH-7, by FK506 and CsA. HLE (A and B) and HuH-7 (C and D) at $2 \times 10^{4}$ cells/well were incubated with various concentrations of FK506 (A and C) and CsA (B and D) for 6 days. ${ }^{* *} \mathrm{p}<0.01 ;{ }^{*} \mathrm{p}<0.05$

by HLE and HuH-7 in the upper compartments of the invasion chambers in the presence or the absence of FK506 and CsA were measured by using TaKaRa EIA kits (TaKaRa BIOMEDICALS, Outsu, Shiga, Japan). Three experiments were performed in triplicate in each time point.

\section{Statistical Analysis}

All values are expressed as means \pm SD. Statistical significance was evaluated using analysis of variance followed by the Student's $t$-test. Values of $\mathrm{p}<0.05$ were considered to be statistically significant.

\section{RESULTS}

Inhibitory effects of FK506 and CsA on the growth of HLE

As shown in Figure 1A, FK506 at a concentration of $1 \mathrm{ng} / \mathrm{mL}$ significantly inhibited the growth of poorly differentiated cell line of HLE during the incubation for $1-5$ days $(p<0.05)$. However, FK506 at a concentration of $10 \mathrm{ng} / \mathrm{mL}$ revealed less inhibitory effect than FK 506 at $1 \mathrm{ng} / \mathrm{mL}$ did and no significant growth inhibition was observed on days 1 and 2. FK506 at a concentra- tion of $100 \mathrm{ng} / \mathrm{mL}$ showed cytotoxicity. CsA at concentrations of $1-1000 \mathrm{ng} / \mathrm{mL}$ inhibited the growth of HLE in a dose-dependent manner, as shown in Figure $1 \mathrm{~B}(\mathrm{p}<0.01)$, but CsA at concentrations over 100ng/ $\mathrm{mL}$ revealed cytotoxicity as shown in the following results.

Inhibitory effects of FK506 and CsA on the growth of $\mathrm{HuH}-\mathrm{H}$

FK506 also significantly inhibited the growth of the well differentiated cell line $\mathrm{HuH}-7$ at concentrations over $1 \mathrm{ng} / \mathrm{mL}$ ( $\mathrm{p}<0.01$ ), but no significant difference in the inhibitory effects were observed at the concentrations of FK506 between 1 and $10 \mathrm{ng} / \mathrm{mL}$ (Figure $1 \mathrm{C})$. CsA at concentrations over $1 \mathrm{ng} / \mathrm{mL}$ inhibited the growth of HuH-7. CsA at $10 \mathrm{ng} / \mathrm{mL}$ revealed further inhibitory effect on days 1 and $2(p<0.01)$, but no significant difference in the inhibitory effect between 1 and $10 \mathrm{ng} / \mathrm{mL}$ was observed after incubation for 3 days (Figure $1 \mathrm{D}$ ). CsA at concentrations over $100 \mathrm{ng} / \mathrm{mL}$ revealed cytotoxic effects on $\mathrm{HuH}-7$ as shown in the following results. 
A

HLE

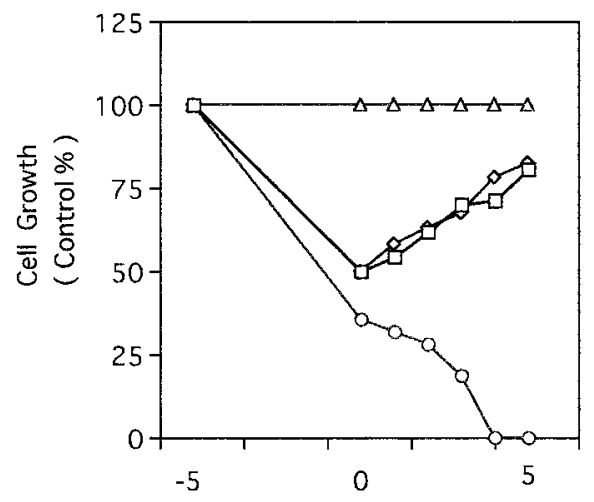

B

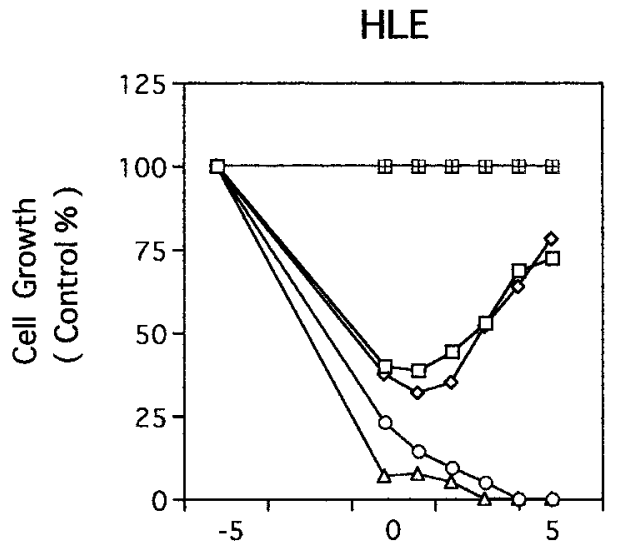

Time ( day )
$\mathrm{HuH}-7$

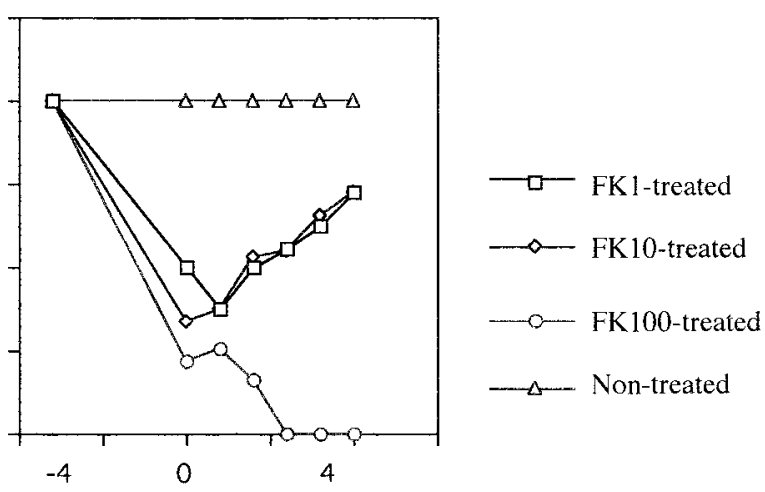

$\mathrm{HuH}-7$

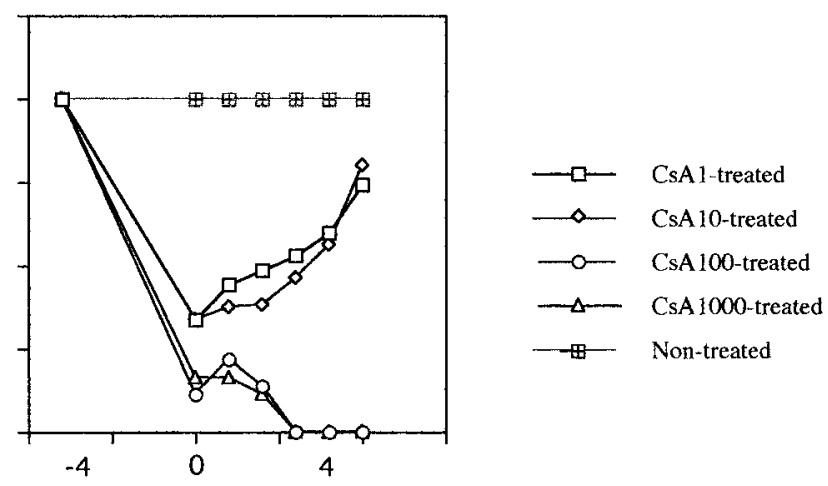

Time ( day )

Figure. 2. The cytotoxic effect of FK506 and CsA on HLE and HuH-7.

FK506 (A) and CsA (B) at various concentrations were added to HLE and HuH-7 cells $\left(2 \times 10^{4}\right.$ cells/ well) for several days and then removed by washing. Day 0 is defined as day on which FK506 and CsA were removed. Then these cells were further cultured in the conditioned media. The results represent the percentage of response compared with the nontreated control.

Evaluation of the FK506 and CsA cytotoxicity on HLE and HuH-7

FK506 and CsA were removed by washing after incubation for 5 days for HLE and for 4 days for $\mathrm{HuH}$ 7 , and these cell lines were further cultured without these immunosuppressors for an evaluation of cell viability. The cells treated with FK506 at a concentration of $100 \mathrm{ng} / \mathrm{mL}$ and those treated with CsA at concentrations over $100 \mathrm{ng} / \mathrm{mL}$ did not grow after removal of these immunosuppressors as shown in Figure $2 \mathrm{~A}$ and $2 \mathrm{~B}$, respectively indicating that these reagents at concentrations over $100 \mathrm{ng} / \mathrm{mL}$ show cytotoxicity.

Inhibitory effects of FK506 and CsA on the invasion of $\mathrm{HLE}$ and $\mathrm{HuH}-7$

FK506 at a concentration of $1 \mathrm{ng} / \mathrm{mL}$ significantly inhibited the invasion of a poorly differentiated HLE but less inhibitory effect was observed at a concentration of $10 \mathrm{ng} / \mathrm{mL}$ (Figure $3 \mathrm{~A}$ and $3 \mathrm{~B})(\mathrm{p}<0.05)$. FK 506 , however, showed no significant inhibitory effect on the well differentiated HuH-7 (Figure 3C). In contrast, $\mathrm{CsA}$ at concentrations of 1 and $10 \mathrm{ng} / \mathrm{mL}$ showed almost no inhibitory effect on the invasion of both HLE and $\mathrm{HuH}-7$.

Measurement of sICAM-1levels in the media of HLE and $\mathrm{HuH}-7$

The levels of sICAM-1 production increased along with an increase in cell number until the peak of cellular proliferation of HLE and HuH-7 around on day 3 and then decreased. Big difference in the levels of of sICAM-1 production was observed between HLE and $\mathrm{HuH}-7$ : the maximal level of sICAM-1 production in the poorly differentiated HLE on day 3 was $773.3 \pm$ 


\section{- FK506}

\section{H L E}

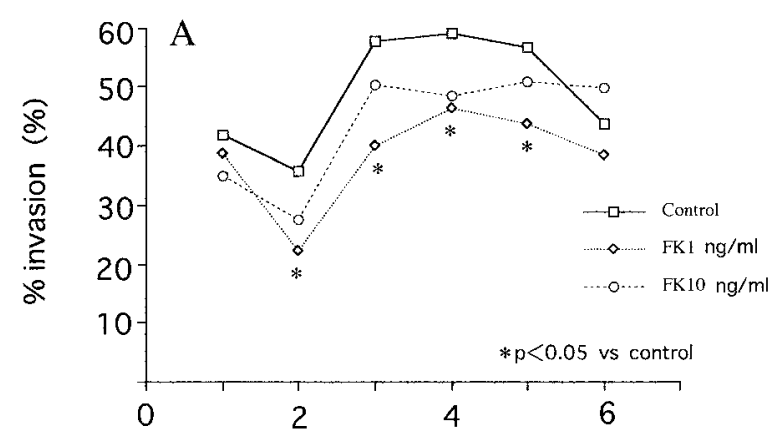

$\mathrm{HuH}-7$

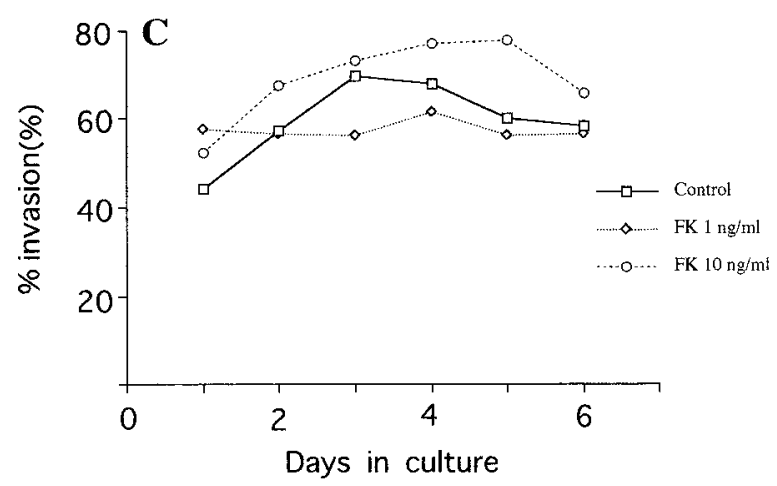

CsA

$H L E$

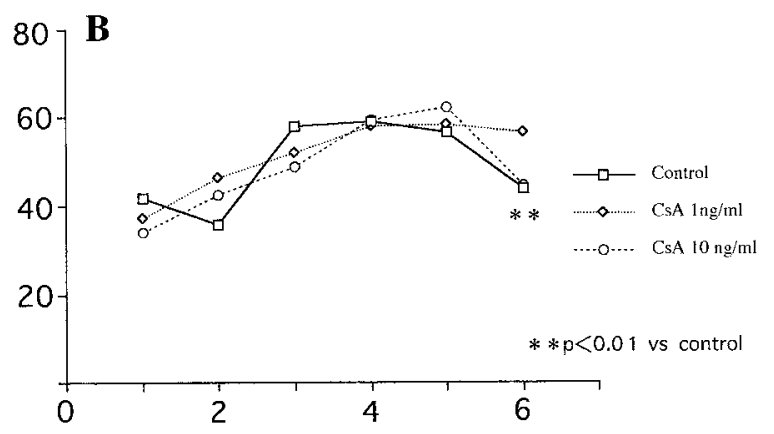

$\mathrm{HuH}-7$

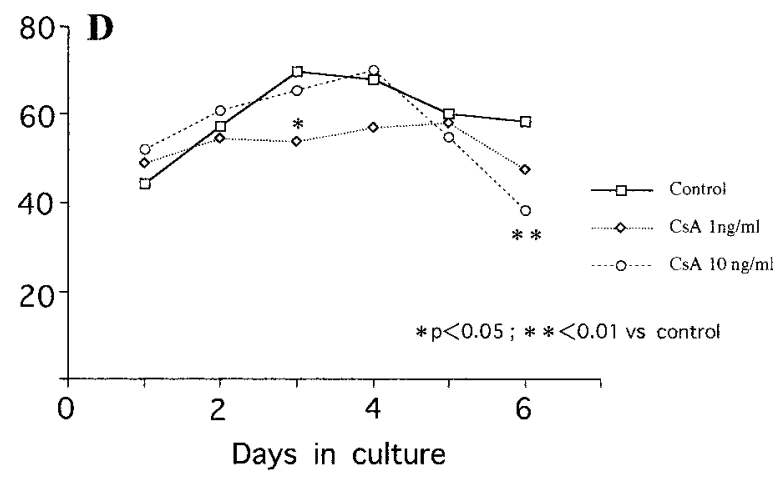

Figure. 3. Inhibition of the invasion of HLE and HuH-7 by FK506 and CsA.

The Matrigel invasion chamber was used to analyze the effect of FK506 and CsA for the invasiveness of HLE cells (A; FK506, B ; CsA) and HuH-7 cells (C ; FK506, D ; CsA) The \% invasion was determined by the methods described under

"Materials and Methods". ${ }^{* *} \mathrm{p}<0.01 ;{ }^{*} \mathrm{p}<0.05$

$20.8 \mathrm{ng} / \mathrm{mL}$ and that of sICAM-1 production in the well differentiated $\mathrm{HuH}-7$ on day 3 was $50.0 \pm 0.5 \mathrm{ng} /$ $\mathrm{mL}$ (Figure 4).

\section{Effects of FK506 and CsA on ICAM-1production in HLE}

FK506 at concentrations of 1 and $10 \mathrm{ng} / \mathrm{mL}$ inhibited the ICAM-1 production in a dose-dependent manner after incubation for 2 days on days 3 and $4(\mathrm{p}<0.01)$ but the inhibitory effect was not evident on the initial days 1 and 2 and the last days on days 5 and 6 (Figure $5 \mathrm{~A})$. CsA at concentrations of $1 \mathrm{ng} / \mathrm{mL}$ and $10 \mathrm{ng} /$ $\mathrm{mL}$ significantly inhibited the ICAM-1 production during the incubation time $(\mathrm{p}<0.01)$ except the last experimental days on days 5 and 6 .

\section{DISCUSSIOIN}

Permeation of micro cancer cells through the basement membrane in the process of cancer recurrence in liver grafts is a principal problem in liver transplantation. Unlike normal liver, the basement membranes in hepatic cirrhosis, liver cancer, inflammatory reac- tions during grafting, and ischemic disorder, become thick by producing ECM(1-3). Klintmalm et al . reported that the prognosis of liver transplantation for the $5 \mathrm{~cm}$ or less HCC is better in poorly-differentiated carcinoma than in well-differentiated carcinoma, indicating that the histological type of liver cancer at the time of liver transplantation is important (4). To clarify the effects of immunosuppressors during the perioperative period of transplantation on cancer recurrence in liver grafts, we used a well-differentiated HCC cell line producing AFP, HuH-7, and a poorlydifferentiated HLE cell lines of HCC $(5,6)$ in the invasion assay by using the invasion chamber, since the structure of the thick basement membranes is similar to that of the invasion chamber used in this study (7-9). In this model, liver cancer cells move from the upper to lower chambers through the cell membrane, the conditions being similar to those of cancer cells present in the recipient's blood which invade the liver graft via the portal vein or hepatic vein system.

Considering the results of the cytotoxicity of FK 506 and CsA for HLE or HuH-7, FK506 and CsA at concentrations of $1-10 \mathrm{ng} / \mathrm{mL}$ were used in the invasion 

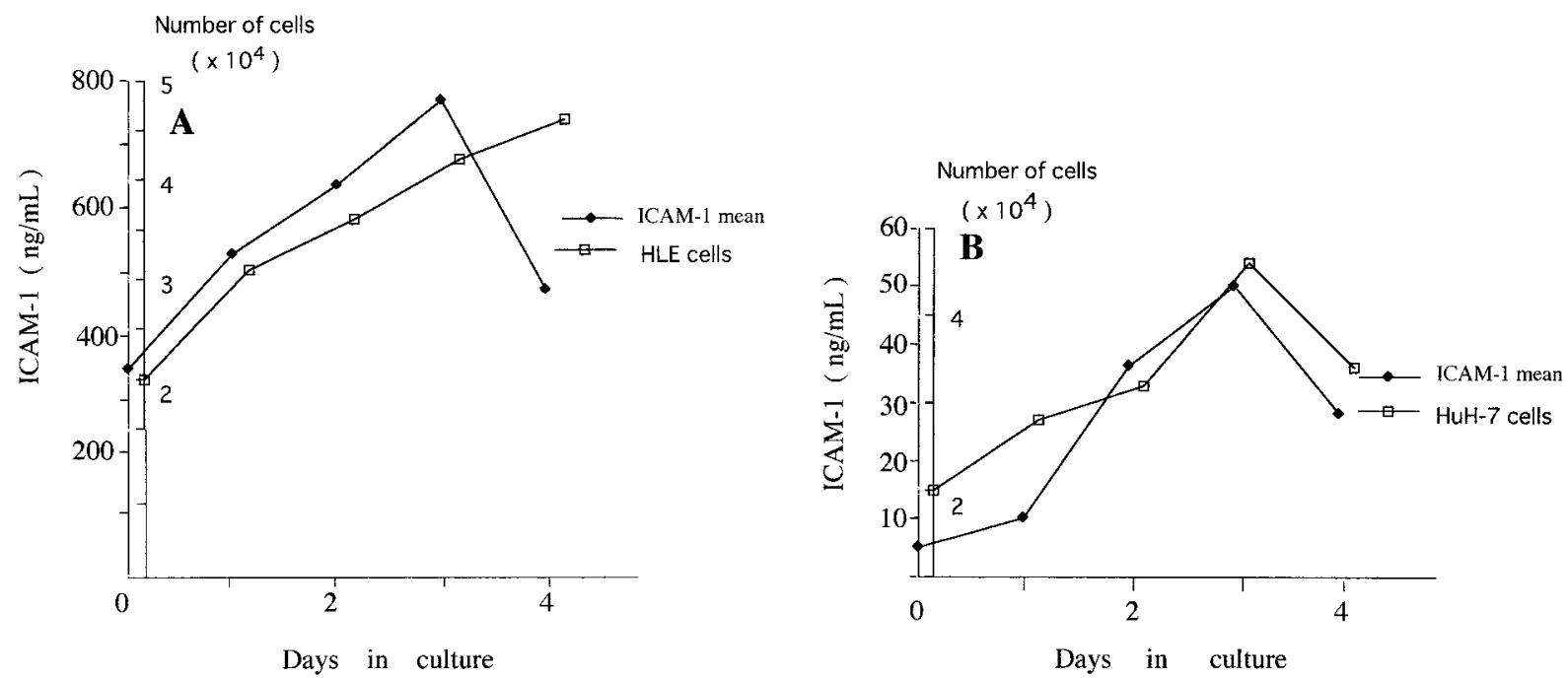

Figure. 4. Time course of sICAM-1 production in HLE and HuH-7.

The sICAM-1 production by HLE cells (A) and HuH-7 cells (B) were measured as described under "Materials and Methods".

assay. These concentrations are close to the blood through values of FK506 and CsA clinically used in liver transplantation. FK506 at 1 and $10 \mathrm{ng} / \mathrm{mL}$ inhibited the invasion activity of a poorly differentiated HLE after treatment for 2-5 days in culture, but there was no significant difference in the inhibitory effects between these two concentrations. FK506 at 1 and $10 \mathrm{ng} / \mathrm{mL}$, however, did not inhibit the invasion of a well differentiated HuH-7. In contrast, CsA did not show any inhibitory effects on the invasion activity of both HLE and HuH-7 at concentrations of 1 and 10 $\mathrm{ng} / \mathrm{mL}$.

The effects of FK506 and CsA on the production of sICAM-1were investigated. ICAM-1 is involved in adhesion of cancer cells to vascular endothelial cells, which is necessary as the first step, entrance into the metastasizing tissue (grafted liver in liver transplanta- tion) of infiltrative metastasis by cancer cells disseminated in the peripheral blood $(10,11)$. FK506 at concentrations of 1 and $10 \mathrm{ng} / \mathrm{mL}$ inhibited the sICAM- 1 production in the upper chamber of HLE at the proliferation stage, suggesting that FK506 inhibits adhesion of cancer cells to ECM of the grafted liver by inhibiting ICAM-1 production. Since FK506 at $1 \mathrm{ng} / \mathrm{mL}$ inhibited sICAM-1 more strongly than FK506 at 10 $\mathrm{ng} / \mathrm{mL}$, a low concentration of FK506 may be advantageous for prevention of cancer recurrence in the transplanted liver when used in liver transplantation for liver cancer in actual clinical practice. In addition, it has been reported that FK506 inhibited expression of ICAM-1 around the portal vein and hepatic veins in a rat liver ischemia-perfusion experiment (12). Furthermore, possibility of intrahepatic metastasis via the portal vein and hepatic veins (13) and increased ICAM-1
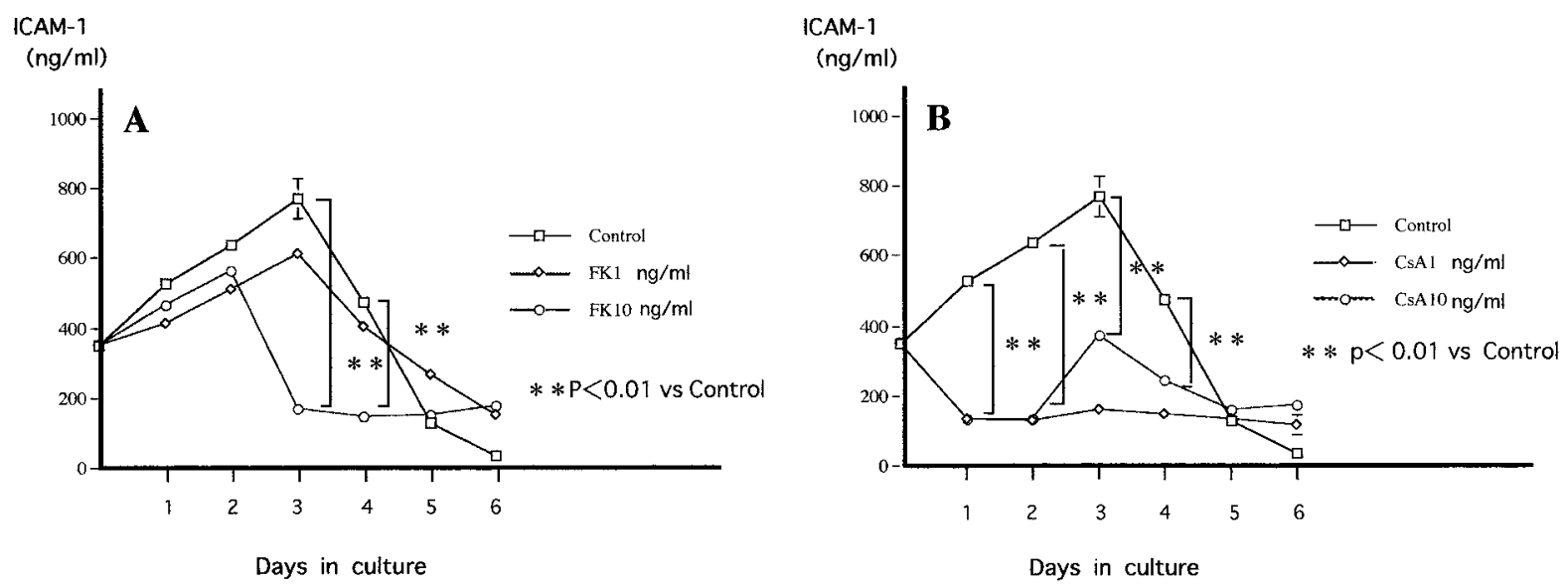

Figure. 5. Inhibitory effects of FK506 and CsA on the production of sICAM-1 in HLE.

(A) Inhibition of sICAM-1 production by FK506 at 1 and $10 \mathrm{ng} / \mathrm{mL}$; (B) Inhibition of sICAM- 1 production by CsA at 1 and $10 \mathrm{ng} / \mathrm{mL} .{ }^{* *} \mathrm{p}<0.01$ 
production with the progression of intrahepatic metastasis have been reported $(10,11)$. Considering of these findings, FK506 was suggested to inhibit recurrence in transplanted liver via inhibition of ICAM-1 production. Although CsA also inhibited the production of sICAM-1in HLE, it did not inhibit or transiently and a little inhibited the invasion. Further studies on the mechanisms of the inhibitory effect of FK506 and CsA on the invasion of HLE are now under investigation.

Generally, immunosuppressors promote growth of tumors according to previous reported (14), but not within a specified concentration range in a report (15). This study showed that FK506 has an inhibitory effects on the production of ICAM-1, and on the invasion of liver cancer cells at 1 and $10 \mathrm{ng} / \mathrm{mL}$. These results suggest that FK506 treatment is clinically useful for the inhibition of micro liver cancer cell invasion in liver transplantation.

\section{REFERENCES}

1. Ueno T, Tanikawa K: Vascular endothelial cells in the liver: Morphology and function of hepatic sinusoidal endothelial cells. SAIBOU 28 (in Japanese) : 509-514, 1996

2. Kin M, Torimura T, Ueno T, Inuzuka S, Tanikawa $\mathrm{K}$ : Sinusoidal capillarization in small hepatocellular carcinoma. Pathol Int 44 : 771-778, 1994

3. Ichida T, Hata K, Yamada S, Hatano T, Nomoto $\mathrm{M}$, Asakura $\mathrm{H}$ :Fine structure and immunohistochemical study of tumor endothelial cells on hepatocellular carcinoma. J Jpn Res Soc Gastroenterol Carcinogenesis 1: 179-182, 1989

4. Klintmalm GB : Liver transplantation for hepatocellular carcinoma: A registry report of the impact of tumor characteristics on outcome. Ann Surg $228:$ 479-490, 1998

5. Doi I, Namba M, Sato J : Establishment and some biological characteristics of human hepatoma cell lines. Gann $66: 385-392,1975$

6. Nakabayashi H, Taketa K, Yamane T, Miyazaki M, Miyano K, Sato J : Phenotypical stability of a human hepatoma cell line, $\mathrm{HuH}-7$, in longterm culture with chemically defined medium. Gann 75 : 151-158, 1984

7. Ichida T, Miyagiwa M, Okada K, Hata K, Sasaki $\mathrm{H}$, Asakura $\mathrm{H}$ : An attempt of in vitro portal invasion model of hepatocellular carcinoma utilizing permeable collagen membrane. Hum Cell $2: 165-172,1989$

8. Kamiyama $\mathrm{T}$, Une $\mathrm{Y}$, Uchino J : The role of urokinase type plasminogen activator (u-PA) and u$\mathrm{PA}$ receptor (u-PAR) in the invasion of human hepatocellular carcinoma cell lines. Int J Clin Oncol $1: 69-74,1996$

9. Hasegawa Y, Takada M, Yamamoto M, Saitoh $\mathrm{Y}$ : The gradient of basic fibroblast growth factor concentration in human pancreatic cancer cell invasion. Biochim Biophys Res Commum 200 : 1435-1439, 1994

10. Hyodo I, Jinno K, Tanimizu M, Doi T, Nishikawa Y, Hosokawa Y, Moriwaki S : Intercellular adhesion molecule-1 release from human hepatocellular carcinoma. Cancer Detect Prev 20:308315, 1996

11. Taketomi A, Takenaka K, Matsumata T, Shimada M, Higashi H, Shirabe K, Itasaka H, Adachi E, Maeda T, Sugimachi K : Circulating intercellular adhesion molecule- 1 in patients with hepatocellular carcinoma before and after hepatic resection. Hepatogastroenterology 44 : 477-483, 1997

12. Wakabayashi H, Karasawa Y, Tanaka S, Kokudo Y, Maeba T : The effect of FK506 on warm ischemia and reperfusion injury in the rat liver. Surg Today 24 : 994-1002, 1994

13. Ohtsubo T, Takasaki K, Aruga J : Therapeutic strategy based on tumor spread for hepatocellular carcinoma. Shokakigeka 21(in Japanese) : 417423, 1998

14. Yokoyama I, Hayashi S, Kobayashi T, Negita M, Yasutomi M, Uchida K, Takagi $\mathrm{H}$ : Immunosuppressive drugs and their effect on experimental tumor growth. Transpl Int $8: 251-255,1995$

15. Tanabe A: Effect of FK506 on the growth of experimental liver malignancy. Tokyo Jikeikai Medical Journal 109 (in Japanese) :243-249, 1994 